\title{
ДО ПИТАННЯ СМЕРТНОСТІ НАСЕЛЕННЯ В РЕЗУЛЬТАТІ САМОРУЙНІВНОЇ ПОВЕДІНКИ
}

\author{
ДУ «Український інститут стратегічних досліджень Міністерства охорони здоров'я України», \\ м. Київ, Україна
}

\begin{abstract}
Мета: вивчити та проаналізувати рівень саморуйнівної поведінки населення України.
Матеріали і методи. Матеріалами дослідження стали дані галузевої статистичної звітності за період 2011-2015 років. У ході роботи використано статистичний та бібліосемантичний методи.

Результати. Отримані результати вказують на високий рівень самогубств населення України 3 тенденцією до його зменшення. Показники самогубств населення відрізняються за регіонами країни. Враховуючи недосконалість статистичної звітності, отримані дані можуть бути недостатньо об'єктивними.

Висновки. Ситуація щодо самогубств в країні потребує розробки державної програми зі збереження психічного здоров'я населення.
\end{abstract}

КЛЮчОВІ СЛОВА: самогубство, показник, протидія.

Самогубства - це глобальна проблема, яка охопила увесь світ. Незважаючи на думку, що самогубства більше поширені в країнах із високим достатком громадян, насправді $75 \%$ самогубств стається в країнах із середнім та низьким рівнем доходів населення. Самогубства $є$ розповсюдженою причиною смерті в різних вікових групах населення. Крім того, що люди помирають або страждають у результаті скоєної суїцидальної спроби, випадки самогубства завдають важких непрямих збитків сім'ям та друзям, а також місцевим громадам та країні в цілому [1;4].

Щороку у результаті самогубства помирає понад 800000 людей. Це друга за частотою причина смерті у віці від 15 до 29 років. Існують дані, що серед дорослого населення на кожного загиблого в результаті самогубства припадає понад 20 осіб, які скоїли суїцидальну спробу [6].

Слід зазначити, що реєстрація самогубств $€$ складною багаторівневою процедурою, яка включає медичні та юридичні аспекти і залучає ряд офріційних державних органів. Найчастіше самогубства реєструються невірно, тобто без дотримання фрормулювань Міжнародної класифрікації хвороб і проблем, що пов'язані зі здоров'ям 10-го перегляду (MKX-10): «випадки пошкодження з невизначеними намірами» (коди Ү10-Ү34), «нещасні випадки» (коди V01-X59), «наслідки нападу 3 метою убивства чи нанесення пошкоджень» (коди Х85-Y09), «неуточнені та невідомі причини смерті» (коди R95-R99) [2;3;5].

Мета роботи: вивчити та проаналізувати рівень самогубств населення України.

(с Г.О. Слабкий, Н.С. Защик, 2016
Матеріали і методи. Матеріалами дослідження стали дані державної статистичної звітності за період 2012-2015 років. У ході дослідження використано статистичний та бібліосемантичний методи. Статистичні дані за 2014 і 2015 рp. наведені без урахування даних 3 тимчасово окупованої території Автономної Республіки Крим і м. Севастополя та частини зони проведення антитерористичної операції.

Результати дослідження та їх обговорення. Дані щодо смертності населення України внаслідок навмисного самоушкодження за їх розподілом за місцем проживання та статтю в 2012-2015 рр. наведено у таблиці 1. Як видно з таблиці, рівень смертності населення України від навмисного самоушкодження за роки дослідження має тенденцію до зниження з показником 18,847 на 100 тис. населення в 2015 році. Найвищий рівень показника зареєстровано у 2013 р. - 20,591. Показник смертності населення України від навмисного самоушкодження відрізняється за типами поселення. Так, показник у міських поселеннях $(14,028)$ у $1,997(p \leq 0,05)$ разу менший, ніж у сільській місцевості $(28,011)$. Показник смертності населення України від навмисного самоушкодження також відрізняється залежно від статі - у жінок він у 5,0 $(p \leq 0,01)$ разу нижчий, ніж у чоловіків, $-6,584$ і 32,967 на 100 тис. населення відповідної статі відповідно.

Окремо було проаналізовано показники смертності населення України внаслідок навмисного самоушкодження за місцем розселення та статтю у 2015 р. у розрізі регіонів (табл. 2). Аналіз наведених в таблиці даних державної статистичної 
Таблиця 1. Смертність населення України внаслідок навмисного самоушкодження. Розподіл за місцем проживання та статтю. 2012-2015 рр.

\begin{tabular}{|c|c|c|c|c|c|c|}
\hline \multirow{2}{*}{ Рік } & \multicolumn{2}{|c|}{$\begin{array}{c}\text { Міські поселення } \\
\text { та сільська місцевість }\end{array}$} & \multicolumn{2}{|c|}{ Міські поселення } & \multicolumn{2}{|c|}{ Сільська місцевість } \\
\hline & осіб & на 100000 нас. & осіб & на 100000 нас. & осіб & на 100000 нас. \\
\hline \multicolumn{7}{|c|}{ Обидві статі } \\
\hline 2012 & 9060 & 19,871 & 5025 & 16,014 & 4035 & 28,386 \\
\hline 2013 & 9367 & 20,591 & 5210 & 16,615 & 4157 & 29,415 \\
\hline 2014 & 7970 & 18,534 & 4296 & 14,461 & 3674 & 27,636 \\
\hline 2015 & 7575 & 18,847 & 3899 & 14,028 & 3676 & 28,011 \\
\hline \multirow{2}{*}{ Рік } & \multicolumn{2}{|c|}{$\begin{array}{c}\text { Міські поселення } \\
\text { та сільська місцевість }\end{array}$} & \multicolumn{2}{|c|}{ Міські поселення } & \multicolumn{2}{|c|}{ Сільська місцевість } \\
\hline & осіб & $\begin{array}{l}\text { на } 100000 \text { нас. } \\
\text { відповідної статі }\end{array}$ & осіб & $\begin{array}{l}\text { на } 100000 \text { нас. } \\
\text { відповідної статі }\end{array}$ & осіб & $\begin{array}{l}\text { на } 100000 \text { нас. } \\
\text { відповідної статі }\end{array}$ \\
\hline \multicolumn{7}{|c|}{ Чоловіки } \\
\hline 2012 & 7363 & 34,936 & 4006 & 27,835 & 3357 & 50,226 \\
\hline 2013 & 7549 & 35,868 & 4143 & 28,790 & 3406 & 51,170 \\
\hline 2014 & 6414 & 32,207 & 3398 & 24,900 & 3016 & 48,112 \\
\hline 2015 & 6149 & 32,967 & 3080 & 24,121 & 3069 & 49,396 \\
\hline \multicolumn{7}{|c|}{ Жінки } \\
\hline 2012 & 1697 & 6,922 & 1019 & 5,999 & 678 & 9,003 \\
\hline 2013 & 1818 & 7,438 & 1067 & 6,289 & 751 & 10,046 \\
\hline 2014 & 1556 & 6,740 & 898 & 5,591 & 658 & 9,366 \\
\hline 2015 & 1426 & 6,584 & 819 & 5,397 & 607 & 8,891 \\
\hline
\end{tabular}

звітності вказує на суттєві відмінності показника у різних регіонах України. Найнижчий показник $(5,212)$ зареєстровано у м. Києві, а найвищий у Сумській області $(29,865)$. Різниця становить $5,73$ ( $\mathrm{p} \leq 0,01)$ разу. Різниця даного показника серед міського населення коливається від 4,011 у Львівській до 25,107 у Кіровоградській області і становить 6,26 (ps0,01) разу. Різниця даного показника серед сільського населення коливається від 7,878 у Львівській області до 49,564 у Чернігівській області і становить 6,29 (ps0,01) разу.

Встановлено достовірну різницю у показниках смертності населення внаслідок навмисного самоушкодження між регіонами України за статтю. Так, найнижчий показник серед чоловіків у 2015 р. зареєстровано у м. Києві $(8,561)$, а найвищий у Херсонській області $(44,201)$, що становить 5,16 $(p \leq 0,01)$ разу. Серед жінок найнижчий показник зареєстровано в Кіровоградській $(1,499)$, а найви- щий - у Запорізькій $(11,518)$ області, що становить $7,68$ ( $\mathrm{p} \leq 0,01)$ разу.

За показниками смертності населення внаслідок навмисного самоушкодження між чоловіками та жінками в розрізі регіонів за місцем їх проживання теж зареєстровані достовірні відмінності.

\section{Висновки}

Результати дослідження вказують на високий рівень самогубств населення України з тенденцією до його зменшення. Показники самогубств населення відрізняються за регіонами країни. Враховуючи недосконалість статистичної звітності, отримані дані можуть бути недостатньо об'єктивними. Ситуація щодо самогубств в України потребує розробки державної програми із збереження психічного здоров'я населення.

Перспективи подальших досліджень пов'язані $з$ вивченням ефективності діяльності із профрілактики самогубств серед населення України.

\section{Список літератури}

1. Комплексный план действий в области психического здоровья на 2013-2020 гг. Женева : Всемирная организация здравоохранения, 2013 [Электронный документ]. - Режим доступа : http://apps.who.int/gb/ebwha/pdf_files/WHA66/ A66_R8-ru.pdf?ua=1 (по состоянию на 20 августа 2014 г.). - Название с экрана.

2. Forty years of increasing suicide mortality in Poland: undercounting amidst a hanging epidemic? / Hofer P., Rockett I. R., Varnik P. [et al.] // BMC Public Health. - 2012. - Vol. 11 (12). - P. 644. 


\begin{tabular}{|c|c|c|c|c|c|c|c|c|c|c|c|c|c|c|c|c|c|c|c|c|c|c|c|c|c|}
\hline \multirow{6}{*}{ 站紊 } & \multirow[t]{2}{*}{ 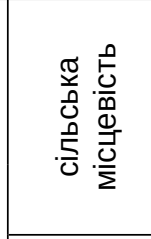 } & 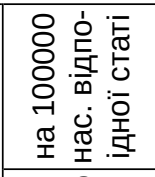 & $\begin{array}{l}\sim \\
\sim \\
\infty \\
\infty\end{array}$ & $\begin{array}{l}0 \\
0 \\
0 \\
0\end{array}$ & 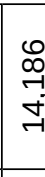 & $\begin{array}{l}\text { O } \\
\text { o } \\
0 \\
0 \\
-1\end{array}$ & $\begin{array}{l}8 \\
\text { gे } \\
\dot{\sigma}\end{array}$ & $\begin{array}{l}0 \\
-1 \\
0 \\
0 \\
-1\end{array}$ & $\begin{array}{l}1 \\
7 \\
0 \\
0\end{array}$ & $\begin{array}{l}-1 \\
\stackrel{1}{N} \\
\infty\end{array}$ & $\begin{array}{l}\tilde{\mho} \\
\mathfrak{y} \\
\dddot{m}\end{array}$ & $\begin{array}{l}\text { No } \\
0 \\
0 \\
0 \\
0\end{array}$ & $\begin{array}{l}m \\
\stackrel{m}{m} \\
- \\
-1\end{array}$ & न्ञ & 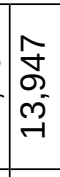 & 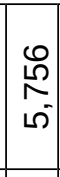 & 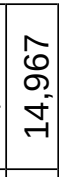 & $\left|\begin{array}{l|}0 \\
\infty \\
\stackrel{-1}{m} \\
m\end{array}\right|$ & $\begin{array}{l}8 \\
8 \\
\infty \\
1-1\end{array}$ & 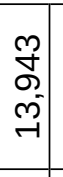 & 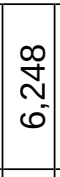 & \begin{tabular}{c}
\multirow{T}{N}{} \\
$m$ \\
-1 \\
-1
\end{tabular} & $\begin{array}{l}8 \\
\circ \\
-1 \\
6 \\
-1\end{array}$ & $\mid \begin{array}{c}\circ \\
\stackrel{0}{n} \\
\\
\end{array}$ & $\begin{array}{l}\text { ○ } \\
\text { ○. } \\
0\end{array}$ \\
\hline & & $\frac{0}{8}$ & $\stackrel{\text { m }}{\circ}$ & 궁 & P & ㅇ & $\stackrel{\infty}{\sim}$ & ले & $\stackrel{9}{\circ}$ & $\vec{m}$ & 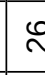 & $m$ & $\mathbb{N}$ & คำ & $\vec{\gamma}$ & $\underset{\sim}{\infty}$ & $\stackrel{\infty}{\sim}$ & 어 & $\mathbb{N}$ & m & $\stackrel{9}{\sim}$ & $m$ & m & ৩ & 0 \\
\hline & \multirow[t]{2}{*}{ 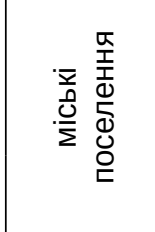 } & 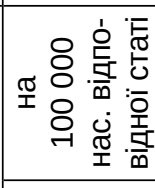 & 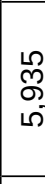 & $\begin{array}{l}\infty \\
\stackrel{0}{0} \\
\stackrel{\sim}{N}\end{array}$ & $\begin{array}{c}\underset{7}{\sim} \\
\infty \\
\infty\end{array}$ & \begin{tabular}{|l}
8 \\
$\infty$ \\
$\infty$ \\
10
\end{tabular} & \begin{tabular}{|l}
$\infty$ \\
\multirow{5}{*}{} \\
0
\end{tabular} & 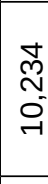 & $\begin{array}{l}m \\
0 \\
0 \\
\sigma\end{array}$ & \begin{tabular}{l}
\multirow{0}{0}{} \\
- \\
$\sigma$
\end{tabular} & $\mid \begin{array}{l}0 \\
0 \\
0 \\
0\end{array}$ & $\begin{array}{l}\text { L } \\
0 \\
\text { i } \\
\text { i }\end{array}$ & $\frac{\text { N }}{\tilde{\sigma}}$ & 守 & 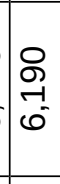 & $\left|\begin{array}{c|}m \\
⿱ \\
0 \\
\omega \\
\omega\end{array}\right|$ & $\left|\begin{array}{l}1 \\
\tilde{m} \\
0 \\
N\end{array}\right|$ & $\mid \begin{array}{l}8 \\
6 \\
-1 \\
-i\end{array}$ & $\mid \begin{array}{l}\hat{0} \\
\tilde{n} \\
\sim \\
\sim\end{array}$ & $\begin{array}{l}\infty \\
\stackrel{2}{0} \\
\infty\end{array}$ & $\begin{array}{c}m \\
m \\
\infty \\
m \\
m\end{array}$ & $\begin{array}{c}\text { Dे } \\
\text { m } \\
\infty \\
\infty\end{array}$ & 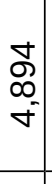 & $\left|\begin{array}{c}n \\
-1 \\
\infty \\
m \\
m\end{array}\right|$ & $\begin{array}{l}\hat{-} \\
\vec{m} \\
\sim \\
\sim\end{array}$ \\
\hline & & $\frac{0}{\overline{8}}$ & $\stackrel{\sim}{\sim}$ & $r$ & $\underset{\sim}{\mathbb{్}}$ & $\stackrel{m}{N}$ & $\stackrel{0}{\sim}$ & $\stackrel{\varrho}{\sim}$ & $\stackrel{m}{r}$ & $\stackrel{\Xi}{\sim}$ & m & ᄀે & $\stackrel{R}{N}$ & 뉴 & 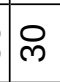 & $\stackrel{\text { L }}{\sim}$ & $\tilde{m}$ & 10 & $\stackrel{\infty}{\sim}$ & ๓ి & $\stackrel{\llcorner}{\sim}$ & $\tilde{m}$ & $\stackrel{\infty}{\rightarrow}$ & $\infty$ & ల్లి \\
\hline & \multirow{2}{*}{ 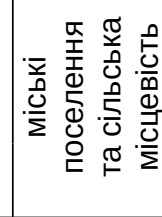 } & 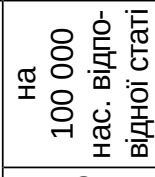 & 呑 & $\begin{array}{l}\stackrel{\rho}{0} \\
\stackrel{m}{\sim} \\
\sim\end{array}$ & $\begin{array}{l}0 \\
\stackrel{9}{7} \\
\sigma\end{array}$ & \begin{tabular}{l}
8 \\
\& \\
\multirow{2}{*}{}
\end{tabular} & $\begin{array}{l}2 \\
\infty \\
0 \\
10\end{array}$ & 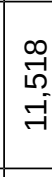 & 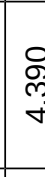 & 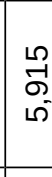 & $\mid \begin{array}{c}\infty \\
\infty \\
m \\
z\end{array}$ & $\underset{-}{\stackrel{g}{9}}$ & $\begin{array}{l}\Omega \\
\underset{1}{-1} \\
\infty\end{array}$ & $\begin{array}{l}0 \\
\infty \\
\infty \\
\infty\end{array}$ & $\underset{\sigma}{-}$ & $\mid$\begin{tabular}{c|}
0 \\
8 \\
+ \\
5 \\
\end{tabular} & \begin{tabular}{|l|}
$\infty$ \\
0 \\
$\infty$ \\
$\sigma$ \\
$\sigma$
\end{tabular} & $\mid \begin{array}{c}0 \\
0 \\
0 \\
-1 \\
\end{array}$ & $\mid \begin{array}{c}- \\
\mathfrak{T} \\
\mathbf{m}\end{array}$ & $\begin{array}{l}0 \\
0 \\
\infty \\
0 \\
0\end{array}$ & 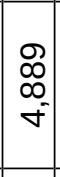 & 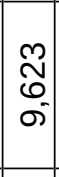 & 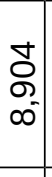 & $\left|\begin{array}{c}8 \\
0 \\
0 \\
\omega\end{array}\right|$ & $\begin{array}{l}\tilde{y} \\
\tilde{n} \\
\sim\end{array}$ \\
\hline & & $\frac{1}{0}$ & 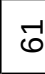 & $\stackrel{\Xi}{\sim}$ & ָِ & กี & m & 윽 & $\approx$ & 饮 & 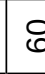 & $\stackrel{\sim}{\sim}$ & เก & $\underset{\exists}{ت}$ & I & $m$ & 8 & $\begin{array}{l}\stackrel{1}{\sim} \\
-1\end{array}$ & ட̊ & $\widetilde{6}$ & ले & 10 & மூ & $\stackrel{\infty}{\sim}$ & లి \\
\hline \multirow{6}{*}{ 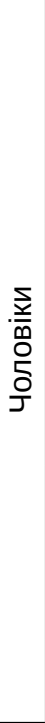 } & \multirow[t]{2}{*}{ 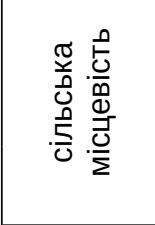 } & 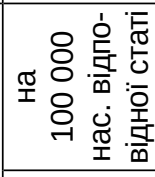 & $\begin{array}{l}\text { L } \\
\text { on } \\
\text { in }\end{array}$ & $\begin{array}{l}\text { o } \\
\text { qे } \\
\text { is }\end{array}$ & 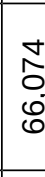 & 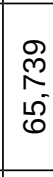 & $\begin{array}{l}\hat{N} \\
\infty \\
\hat{N}\end{array}$ & 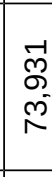 & $\begin{array}{l}\text { P } \\
\text { ร } \\
\text { ని }\end{array}$ & $\begin{array}{l}\stackrel{2}{\Omega} \\
- \\
-1 \\
6\end{array}$ & $\begin{array}{l}2 \\
\infty \\
0 \\
0 \\
\tilde{c}\end{array}$ & $\begin{array}{l}0 \\
0 \\
1 \\
10 \\
7\end{array}$ & 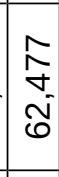 & 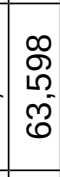 & 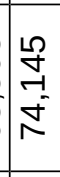 & $\left|\begin{array}{c|}0 \\
0 \\
0 \\
-1 \\
\gamma\end{array}\right|$ & 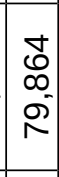 & $\left|\begin{array}{l}n \\
\stackrel{1}{N} \\
\\
N\end{array}\right|$ & $\left|\begin{array}{l|}0 \\
0 \\
0 \\
+ \\
0 \\
m\end{array}\right|$ & $\begin{array}{l}1 \\
-1 \\
8 \\
8\end{array}$ & 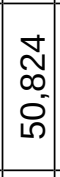 & 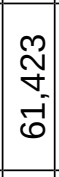 & \begin{tabular}{l}
\multirow{N}{m}{} \\
8 \\
$\delta$
\end{tabular} & $\left|\begin{array}{l}-1 \\
0 \\
0 \\
0 \\
\sim\end{array}\right|$ & $\begin{array}{l}8 \\
8 \\
0\end{array}$ \\
\hline & & $\frac{\circ}{0}$ & 尺े & $\stackrel{\text { I }}{ }$ & $\widehat{\underline{G}}$ & ֶి & ఫ & $\stackrel{\text { g }}{\mathrm{G}}$ & 요 & $\underset{\substack{+-}}{+}$ & 。 & $\stackrel{\llcorner}{\wedge}$ & 윽 & 守 & প্ণ & $\underset{\sim}{\stackrel{\sim}{\sim}}$ & $\underset{\sim}{\tilde{\sim}}$ & $\hat{N}$ & ৫) & $\begin{array}{l}9 \\
\vec{G}\end{array}$ & $\underset{\sim}{\mathrm{m}}$ & $\begin{array}{l}m \\
\stackrel{m}{\sim} \\
\sim\end{array}$ & $\begin{array}{l}N \\
\stackrel{N}{a}\end{array}$ & เి & 0 \\
\hline & \multirow{2}{*}{ 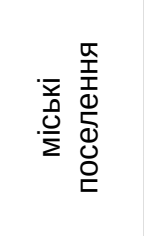 } & 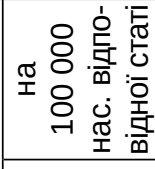 & $\begin{array}{l}\vec{I} \\
\vec{m} \\
\vec{m}\end{array}$ & $\begin{array}{l}\overrightarrow{0} \\
\infty \\
0 \\
\sigma\end{array}$ & $\begin{array}{l}8 \\
\text { Ln } \\
\text { D. } \\
\text { D. }\end{array}$ & 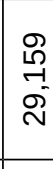 & $\begin{array}{l}\text { 先 } \\
\text { s] }\end{array}$ & $\begin{array}{l}\infty \\
\stackrel{\infty}{2} \\
\text { m. } \\
\text { m. }\end{array}$ & $\mid \begin{array}{l}8 \\
\infty \\
0 \\
0\end{array}$ & 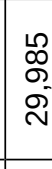 & \begin{tabular}{l} 
g \\
J \\
\multirow{7}{*}{}
\end{tabular} & $\begin{array}{c}\text { N } \\
\text { न } \\
6\end{array}$ & $\begin{array}{l}\stackrel{8}{0} \\
\stackrel{+}{-} \\
\stackrel{m}{m}\end{array}$ & 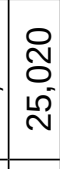 & 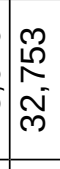 & \begin{tabular}{l}
8 \\
8 \\
0 \\
0 \\
\hdashline
\end{tabular} & $\begin{array}{l}0 \\
\tilde{m} \\
o \\
o \\
\dot{q}\end{array}$ & 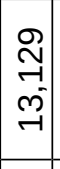 & 足 & \begin{tabular}{l}
$\stackrel{-1}{D}$ \\
\multirow{f}{f}{}
\end{tabular} & ָ̃ & 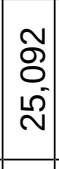 & 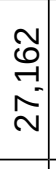 & 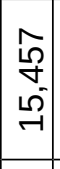 & $\begin{array}{l}-1 \\
6 \\
10 \\
\infty\end{array}$ \\
\hline & & $\frac{\circ}{8}$ & $\overrightarrow{-1}$ & i & \ٌ & ন & ले & $\stackrel{\infty}{\stackrel{N}{N}}$ & เి & 욤 & & เீ & $\underset{\sim}{\sim}$ & $\begin{array}{l}\hat{\infty} \\
-\end{array}$ & $\underset{\sim}{\text { m }}$ & ஜి & $\underset{\sim}{\stackrel{\mathcal{Y}}{\sim}}$ & N & $\begin{array}{l}m \\
m \\
\sim\end{array}$ & $\begin{array}{l}\vec{m} \\
\vec{f}\end{array}$ & $\stackrel{2}{\sim}$ & $\stackrel{-1}{\infty}$ & 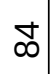 & $\stackrel{\infty}{\sim}$ & $\stackrel{10}{7}$ \\
\hline & \multirow{2}{*}{ 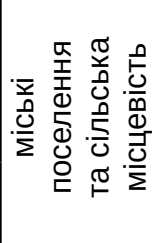 } & 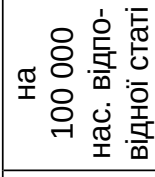 & $\begin{array}{l}\tilde{N} \\
\text { ָे } \\
\text { - }\end{array}$ & 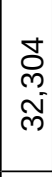 & 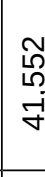 & $\begin{array}{l}\hat{N} \\
m \\
\dot{f}\end{array}$ & 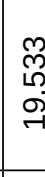 & $\begin{array}{l}\stackrel{-}{\sim} \\
\stackrel{\sim}{\sim}\end{array}$ & $\mid \begin{array}{l}\hat{2} \\
2 \\
2 \\
2\end{array}$ & $\begin{array}{l}\mathcal{N} \\
\mathcal{R} \\
\text { - }\end{array}$ & $\begin{array}{l}1 \\
5 \\
5 \\
15\end{array}$ & $\begin{array}{l}0 \\
0 \\
0 \\
0 \\
\sigma\end{array}$ & 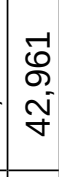 & 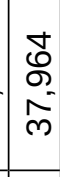 & 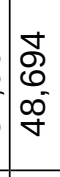 & $\begin{array}{l}\mathbb{N} \\
\tilde{\sigma} \\
-1 \\
\tilde{m}\end{array}$ & 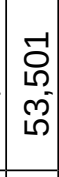 & $\mid$ & $\begin{array}{c}\hat{n} \\
-1 \\
-1 \\
-1 \\
-1\end{array}$ & $\mid \begin{array}{c}0 \\
1 \\
10 \\
0 \\
10\end{array}$ & $\begin{array}{l}0 \\
0 \\
0 \\
0 \\
\tilde{j} \\
m\end{array}$ & $\begin{array}{l}0 \\
\sigma \\
0 \\
0 \\
\sigma\end{array}$ & 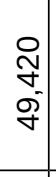 & 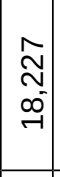 & $\begin{array}{l}-1 \\
0 \\
0 \\
\infty\end{array}$ \\
\hline & & $\frac{}{4}$ & $\begin{array}{l}0 \\
\stackrel{m}{N}\end{array}$ & 号 & స్ర & $\stackrel{\infty}{\stackrel{\leftrightarrow}{N}}$ & $\stackrel{\infty}{\exists}$ & 文 & $\begin{array}{l}\infty \\
\emptyset \\
\bullet\end{array}$ & ঙ্লি & $\approx$ & 구 & $\stackrel{\vec{ఖ}}{\sim}$ & $\underset{\sim}{\stackrel{N}{\sim}}$ & $\underset{\sim}{\mathbb{N}}$ & $\begin{array}{l}0 \\
2 \\
-1\end{array}$ & $\stackrel{\mathbb{N}}{\mathbf{N}}$ & $\begin{array}{l}0 \\
0 \\
-1\end{array} \mid$ & $\stackrel{\mathcal{N}}{\mathbb{N}}$ & 吊 & ì & $\stackrel{\mathbb{N}}{\mathrm{N}}$ & $\begin{array}{l}0 \\
\stackrel{N}{N}\end{array}$ & $\stackrel{\infty}{\sim}$ & $\stackrel{\stackrel{0}{-}}{\underset{7}{7}}$ \\
\hline \multirow{6}{*}{ 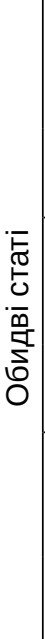 } & \multirow{2}{*}{ 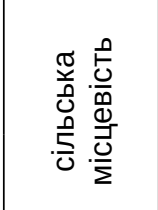 } & 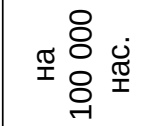 & $\begin{array}{l}\hat{\alpha} \\
\hat{N} \\
0 \\
0\end{array}$ & $\begin{array}{l}\text { m } \\
\text { m } \\
\text { N }\end{array}$ & 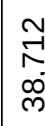 & 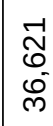 & 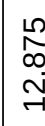 & $\begin{array}{l}m \\
\stackrel{m}{m} \\
\tilde{m} \\
\stackrel{\sigma}{\sigma}\end{array}$ & 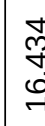 & $\begin{array}{l}\infty \\
0 \\
\infty \\
N \\
m\end{array}$ & \begin{tabular}{l}
$q$ \\
\multirow{2}{m}{} \\
m
\end{tabular} & $\begin{array}{l}\infty \\
\infty \\
\infty \\
r\end{array}$ & $\underset{\stackrel{m}{N}}{\stackrel{m}{n}}$ & 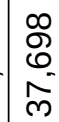 & 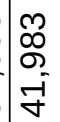 & 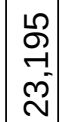 & $\left|\begin{array}{c}8 \\
0 \\
+ \\
5 \\
5\end{array}\right|$ & $\left|\begin{array}{l}\infty \\
0 \\
0 \\
0 \\
-1 \\
-1\end{array}\right|$ & $\begin{array}{l}\tilde{N} \\
\tilde{m} \\
\mathfrak{N}\end{array}$ & $\mid \begin{array}{l}0 \\
0 \\
0 \\
0 \\
ల \\
m\end{array}$ & 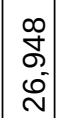 & 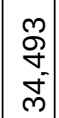 & 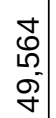 & 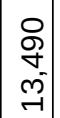 & $\begin{array}{l}8 \\
8 \\
0\end{array}$ \\
\hline & & $\frac{}{4}$ & $\stackrel{\sim}{\sim}$ & $\underset{\underset{\sim}{*}}{\mathbb{2}}$ & స్ & 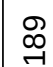 & ๙ָ & $\underset{\sim}{\stackrel{\Delta}{A}}$ & $\stackrel{\infty}{\underset{\exists}{\exists}}$ & $\stackrel{L}{\sim}$ & 吊 & $\stackrel{\infty}{\sim}$ & $\underset{\sim}{\widetilde{m}}$ & \& & $\overrightarrow{\widetilde{N}}$ & $\vec{J}$ & 8 & $\mid \begin{array}{l}\hat{\infty} \\
\mid\end{array}$ & $\begin{array}{l}\infty \\
\stackrel{-}{7}\end{array}$ & $\underset{\sim}{\stackrel{g}{9}}$ & 吕 & $\begin{array}{l}0 \\
0 \\
-1\end{array}$ & $\begin{array}{l}\llcorner \\
\infty \\
\rightarrow\end{array}$ & ㅇ & 0 \\
\hline & \multirow{2}{*}{ 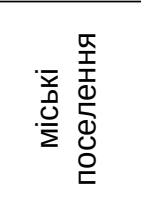 } & 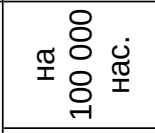 & 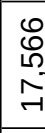 & $\begin{array}{l}9 \\
g \\
0 \\
-1\end{array}$ & ন & $\begin{array}{l}0 \\
0 \\
0 \\
0 \\
0 \\
-1\end{array}$ & 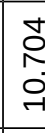 & 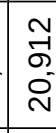 & 天ે & $\begin{array}{l}\mathbb{N} \\
-1 \\
0 \\
-1\end{array}$ & $\begin{array}{l}2 \\
0 \\
1 \\
2 \\
2\end{array}$ & $\begin{array}{l}-1 \\
0 \\
-\end{array}$ & $\begin{array}{l}10 \\
5 \\
0 \\
00 \\
-1\end{array}$ & 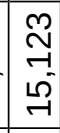 & $\begin{array}{l}\text { 足 } \\
\text { m } \\
\infty \\
\infty \\
-1\end{array}$ & 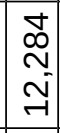 & 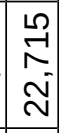 & | & $\begin{array}{l}0 \\
m \\
m \\
N \\
\end{array}$ & \begin{tabular}{|l|}
8 \\
8 \\
N \\
\end{tabular} & 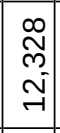 & 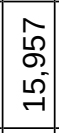 & 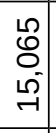 & \begin{tabular}{|l|} 
\\
0 \\
$N$ \\
$\sigma$ \\
\end{tabular} & 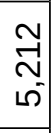 \\
\hline & & $\frac{6}{0}$ & $\underset{-}{-}$ & in & 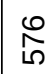 & $\underset{\sim}{\mathbb{Z}}$ & 요 & 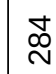 & $\tilde{N}$ & $\underset{-}{\mathbb{A}}$ & 5 & $\widetilde{0}$ & 욤 & $\stackrel{\stackrel{\sim}{\sim}}{\sim}$ & 守 & 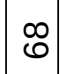 & $\frac{\text { I }}{ \pm}$ & ঙे & $\mid \begin{array}{l}-1 \\
0\end{array}$ & \begin{tabular}{|c|}
0 \\
$\underset{\sigma}{0}$
\end{tabular} & ৪ & $\underset{m}{-}$ & ్ָతి & $\begin{array}{l}0 \\
\text { e }\end{array}$ & 点 \\
\hline & \multirow{2}{*}{ 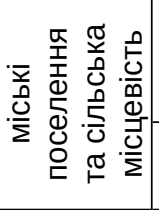 } & 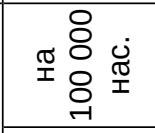 & 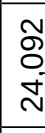 & 㝵 & \begin{tabular}{l}
0 \\
\multirow{2}{*}{} \\
\\
N
\end{tabular} & 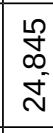 & $\begin{array}{l}\stackrel{2}{0} \\
\text { I } \\
\text { I }\end{array}$ & 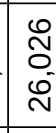 & 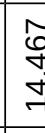 & $\begin{array}{l}\stackrel{0}{2} \\
\stackrel{5}{N} \\
\text { N }\end{array}$ & $\begin{array}{ll} \\
\infty \\
\infty \\
0 \\
0 \\
2\end{array}$ & \begin{tabular}{l}
-1 \\
\multirow{1}{0}{} \\
$\omega$
\end{tabular} & $\begin{array}{l}\text { D } \\
\stackrel{N}{N} \\
\stackrel{d}{N}\end{array}$ & 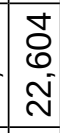 & م & 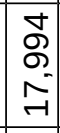 & $\begin{array}{l} \\
0 \\
0 \\
0 \\
\text { N } \\
\end{array}$ & $\mid \begin{array}{c}-1 \\
\tilde{m} \\
-1 \\
-1\end{array}$ & 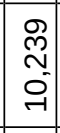 & 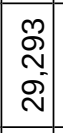 & 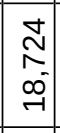 & \begin{tabular}{|l|} 
\\
0 \\
0 \\
\\
\\
\end{tabular} & $\begin{array}{l}\stackrel{L}{n} \\
\stackrel{m}{\sim} \\
\stackrel{N}{N}\end{array}$ & \begin{tabular}{|l|} 
\\
\\
0 \\
-1 \\
-1
\end{tabular} & 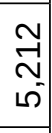 \\
\hline & & $\frac{0}{4}$ & ल & $\begin{array}{c}\infty \\
\infty \\
-1\end{array}$ & & $\stackrel{-1}{m}$ & กี & $\stackrel{\infty}{\sim}$ & 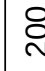 & \& & 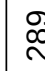 & P & $\stackrel{\mathbb{N}}{\sim}$ & 건 & 足 & $\underset{N}{\stackrel{2}{2}}$ & 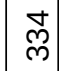 & $\underset{\sim}{\mathfrak{T}}$ & $\begin{array}{l}\mathfrak{R} \\
\mathbb{N}\end{array}$ & $\begin{array}{l}\tilde{m} \\
\text { mे }\end{array}$ & $\stackrel{m}{\sim}$ & $\stackrel{\text { D }}{\text { S }}$ & 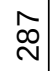 & $\left|\begin{array}{l}0 \\
0 \\
-1\end{array}\right|$ & 록 \\
\hline & & & & & 送 & D. & 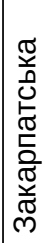 & $\begin{array}{l}\frac{\pi}{2} \\
\frac{1}{m} \\
\frac{0}{0} \\
\frac{0}{0} \\
\frac{1}{0} \\
0\end{array}$ & 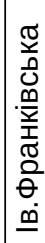 & 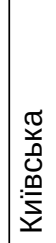 & 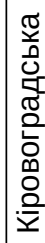 & 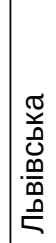 & 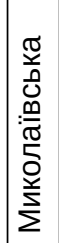 & \begin{tabular}{|l}
$\frac{\pi}{0}$ \\
$\frac{0}{0}$ \\
$\mathbb{E}$ \\
0 \\
0
\end{tabular} & $\begin{array}{l}\text {. } \\
0 \\
0 \\
\widetilde{0} \\
\stackrel{0}{5} \\
\text { 은 }\end{array}$ & 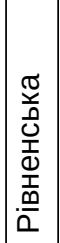 & 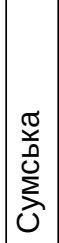 & 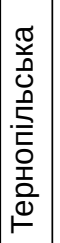 & 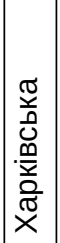 & 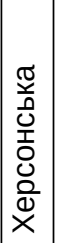 & 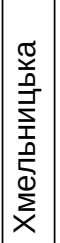 & 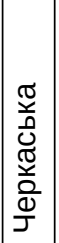 & 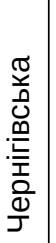 & 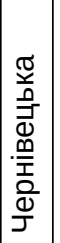 & $\begin{array}{l}: \frac{\emptyset}{\bar{\Sigma}} \\
\dot{\Sigma} \\
\dot{\Sigma}\end{array}$ \\
\hline
\end{tabular}


3. Massive increase in injury deaths of undetermined intent in ex USSR Baltic and Slavic countries: Hidden suicides? I Varnik P., Sisask M., Varnik A. [et al.] // Scand. J. Public Health. - 2010. - Vol. 38 (4). - P. 395-403.

4. Preventing suicide: a global imperative. - Geneva : World Health Organization, 2014 [Electronic resource]. - URL : http:// www.euro.who.int/PubRequest?language=Russian. - Title from screen.

5. Validity of suicide statistics in Europe in relation to undetermined deaths: developing the 2-20 benchmark / Varnik P., Sisask M., Varnik A. [et al.] // In. j. Prev. - 2012. - Vol. 18 (5). - P. 321-5.

6. WHO mortality database documentation: 1 May 2013 update. Geneva: World Health Organization, 2013 [Electronic resource]. - URL : http://www.who.int/ healthinfo/statistics/mortality_rawdata/en/, accessed 19 May 2014. - Title from screen.

\section{К ВОПРОСУ СМЕРТНОСТИ НАСЕЛЕНИЯ В РЕЗУЛЬТАТЕ САМОРАЗРУШАЮЩЕГО ПОВЕДЕНИЯ}

Г.А. Слабкий, Н.С. Защик

ГУ «Украинский институт стратегических исследований Министерства здравоохранения Украины», г. Киев, Украина

Цель: изучить и проанализировать уровень саморазрушающего поведения населения Украины.

Материалы и методы. Материалами исследования стали данные отраслевой статистической отчетности за период 2011-2015 годов. В ходе роботы использованы статистический и библиосемантический методы.

Результаты. Полученные результаты указывают на высокий уровень самоубийств населения Украины с тенденцией к его уменьшению. Показатели самоубийств населения отличаются в регионах страны. Учитывая несовершенство статистической отчетности, полученные данные могут быть недостаточно объективными.

Выводы. Ситуация относительно самоубийств в стране требует разработки государственной программы по сохранению психического здоровья населения.

КЛЮЧЕВЫЕ СЛОВА: самоубийство, показатель, противодействие.

\section{TO THE PROBLEM OF POPULATION MORTALITY DUE TO SELF-DESTRUCTIVE BEHAVIOR G.O. Slabkiy, N.S. Zashchik \\ PE "Ukrainian Institute of Strategic Researches MHC of Ukraine", Kyiv, Ukraine}

Goal of study: to consider and analyze the level of self-destructive behavior of the population in Ukraine.

Materials and methods. The data of branch statistical reports for the period of the years 2011-2015 were used as material for study. Statistical and bibliosemantic methods of study were used in the course of research.

Results. The results obtained indicate the high level of suicides among the population of Ukraine with the tendency to increase. Suicide indices of population differ by regions of the country. Taking into account the inadequacy of statistical accounting and reporting the data may be insufficiently objective.

Conclusions. The situation with suicides in the country requires the development of the State program of preserving mental health of population.

KEY WORDS: suicide, indie, counteraction.

Рукопис надійшов до редакції 18.10.2016 р.

\section{Відомості про авторів:}

Слабкий Геннадій Олексійович - д.мед.н., проф., в.о. директора дУ «Український інститут стратегічних досліджень Міністерства охорони здоров'я України»; тел. служб.: +38(044) 576-41-19.

Защик Наталія Сергіївна - лікар-психіатр КЗ «Острозька обласна психіатрична лікарня» Рівненської обласної ради, пошукувач ДУ «Український інститут стратегічних досліджень Міністерства охорони здоров'я України». 